\title{
Cooperative Learning Model Group Investigation Type and Mathematic Achievement of Elementary School Students
}

\author{
I Ketut Gading ${ }^{1}$ \\ Departement of Guidance and Counselling \\ Universitas Pendidikan Ganesha \\ Singaraja,Indonesia \\ ${ }^{1}$ ketutgading35@gmail.com
}

\author{
Ketut Siti Ajerah ${ }^{2}$, I Gusti Ngurah Japa ${ }^{3}$ \\ Department of Primary School Teacher Education \\ Universitas Pendidikan Ganesha \\ Singaraja,Indonesia \\ 2ajerah_ketut@yahoo.com, ${ }^{3}$ ngrjapa_pgsd@yahoo.co.id
}

\begin{abstract}
This is an experimental research which aimed at investigating the effect of Cooperative Learning Model Group Investigation Type based on Bruner's theory toward Mathematic achievement of grade IV elementary school students. The experimental design used was nonequivalent posttest only control group design. There are 33 grade IV students of SD Negeri 1 Pegayaman assigned as experimental group and 38 grade IV students of Madrasah Iftidaiyah Miftahul Ulum assigned as control group. Cooperative Learning Model Group Investigation type was implemented for 4 months (32 meetings) toward experimental group, meanwhile the control group taught by their teacher using their daily learning model (conventional model). The students' achievement were tested using math achievement test, then analyzed using t-test. The result showed that Cooperative Learning Model Group Investigation type based on Bruner's theory influence the students' math achievement.
\end{abstract}

Keywords-- Cooperative Learning Model, Group Investigation, Math Achievement

\section{INTRODUCTION}

According to Piaget [1], elementary school students that are children of 7 - 12 years old, are at the stage of operational concrete cognitive development. At this stage, the child develops concepts with the help of concrete objects to investigate relationships and models of abstract ideas. At this age, learners have started to think logically. Their logical thinking ability occurs as the result of manipulating concrete objects. Therefore, learning, especially Mathematics learning, for elementary school age students should be implemented with more tools using concrete objects and provides the wider opportunity for students to know and deal with real life situations so that learning becomes interesting and motivate students to study [2].

However, field condition shows that Mathematics is an abstract subject, complicated, and requires precision in calculating especially in using formulas. It causes students to feel bored and less motivated to learn math [3]. This is also shown from the result of preliminary research conducted at SD Negeri 1 Rajabasa Raya in grade V students, that mathematics lessons decrease students' intention because of the minimum variety of learning methods used and lecture methods are frequently used, making teacher centered learning (teacher centered) and makes students passive.

These problems affected the students' learning achievement, especially in Mathematics. The average of Mathematics achievement obtained by students in the final examination is still low and still below the passing grade.

One of the effort that teachers can do to help students to learn are: giving motivation, looking at Mathematics lessons as a fun subject, and finally learning achievement increased significantly is trying to apply cooperative learning model which are relevant to it. One model of cooperative learning that relevant is Group Investigation (GI) model. It was said so because basically this is a learning model that invites students to participate directly in the learning process. Participating directly in this case is that students find their own materials or concepts learned through various sources, whether from teachers, books or internet. Students are involved from the planning, process, until the end of the lesson. The most important thing of this model is to train students to cultivate the ability to think independently [4].

Furthermore, it is stated that in Group Investigation model, students will be able to obtain various kinds of experience. The experience can be obtained by students in research activities, as well as in group activities [4]. The advantages of cooperative learning model Group Investigation type are: 1) improving learning achievement, 2) increasing motivation to learn, 3) creating atmosphere of mutual cooperation and interaction between students and between groups regardless of background. This will have a good impact on students' social attitudes, 4) to train students to have good communication skills, 5) Motivating students to participate and be active in the learning process from the first stage to the final stage of learning [4].

The advantages of group investigation seem to be very useful in improving the process and achievement of themes or subjects. However, in Mathematics learning, especially for elementary school students who are at the cognitive development stage of concrete operational, it needs the help of concrete objects that can be manipulated by students to establish their understanding of the basic concepts of 
Mathematics. Cooperative learning model of group investigation type has not specifically recommended the use of concrete objects as learning aids, especially Mathematics learning, which can be manipulated by students to establish students' understanding of Mathematical concepts. Therefore, the implementation of cooperative learning model of group investigation type in this research was completed by applying Bruner's theory.

Bruner's theory is closely related to Mathematics learning and cooperative learning model of Group investigation type because Bruner's theory is basically provide a direct understanding for students about a material or concept learned by manipulating objects or props. Bruner in his method of discovery revealed that in Mathematics learning, students must find out for themselves the knowledge they need. "Finding" here is primarily "discovery", or it can also find something entirely new (invention) [5]. Finding themselves in Bruner's theory means that students are able to find the material or concept that is being learned by doing various activities, for example, by manipulating objects, observing directly the object being studied or the other. Another opinion was also expressed by [6] which stated that, Bruner's theory was a teaching that emphasized the importance of an understanding of the material structure of a learned science, the need for active learning as the basis of the true understanding and value of inductive thinking in learning. In this theory there were three stages, namely: enactive, iconic and symbolic. To be able to apply this theory well, a teacher must understand first about the material that they are going to teach.

Students' achievement is the ability that students gain after following the learning process [7]; [8]. Students' achievement shows the success of students in learning, also shows the success of teachers in teaching. [9]

Based on the problems related to Mathematics and students' achievement as mentioned earlier, this study was conducted with the aim of answering the main problem whether Cooperative Learning Model Group Investigation Group (GI) Based on Bruner's Theory has an effect on students' achievement of Mathematics of Grade IV elementary school students.

\section{METHOD}

This research was conducted at Elementary School of Gugus II of Sukasada District, Buleleng Regency, Bali Province in the second semester of academic year 2016/2017. The type of this research is a quasi-experimental with a nonequivalent post-test only control group design.

A total of 33 grade 4 students of SD Negeri 1 Pegayaman were involved as experimental group and 38 students of Madrasah Iftidaiyah Miftahul Ulum were involved as control group. Both groups were randomly selected from the 10 classes of grade IV in Gugus II, Sukasada District who has the average of learning achievement does not significantly different. The experimental and control group were between 911 years old. The experimental group consisted of 15 boys and
18 girls, while the control group consisted of 17 boys and 21 girls.

For 4 months (32 times) the experimental group taught by using Cooperative Learning Group Investigation model based on Bruner's theory, while the control group taught by the learning model that was implemented daily by the teacher (Conventional learning model). After the treatment, both groups were tested for their mastery of the subject matter by using achievement test constructed by the researcher, which has been tested the content validity, item validity, difficulty level, level of differentiation, and reliability. In order to test the hypothesis stating that cooperative learning model Group Investigation type based on Bruner's theory have an effect toward the result of Mathematics achievement of fourth grade student of elementary school, the data was analyzed using ttest.

\section{FINDINGS AND DISCUSSION}

The result of data analysis for hypothesis test by using ttest occupying SPSS program, found t value equal to 6.999 with significance level of 0.000 . The significance level implied that the value of $t$ analysis was significant, and it means the hypothesis stated that there was an effect of cooperative learning model type Group Investigation based on Bruner's theory that already tested empirically.

The results of this study were in accordance with the results of other studies found that the group investigation model could improve learning achievement of vocational school students [10]. It was also found that cooperative learning achieved much higher marks on post-test retention achievement and knowledge than lecture-based learning [11]. Compared to the traditional way, the implementation of cooperative learning methods in fact can improve the academic achievement of British students [12]. Later, it was found that students who were taught by cooperative learning significantly perform better than conventional students. Altun in his research stated that cooperative learning method has a good influence on learning [14]. Cooperative learning enables learners to receive positive feedback from the thinking process, thereby enhancing academic achievement better than traditional teaching and promoting interactive group learning experiences [13],[15],16]. Other research found cooperative learning positively affected students' achievement enrolled in Education subjects [16]. The cooperative learning group gained a higher achievement than the traditional class [17].

The findings of this study and the findings of previous research relevant to the findings of this study prove that cooperative learning models effectively improve the learning process and achievement. In addition to improving process and learning achievement, cooperative learning models have a nurturing effect on intrinsic and interpersonal skills. [18] This is possible because in the implementation of cooperative learning models students were required to work together in completing tasks. The tasks were designed in such a way by the teacher that students inevitably have to work together. Without cooperation, the tasks will be difficult to solve. In addition, in cooperative learning, students who are cleverer should help less clever students. If they are not assisted, 
students who are less clever will hamper the completion of group tasks resulting in all members of the group get an unfavorable value.

Various research findings have proved the effectiveness of cooperative learning model in improving process and learning outcomes. However, this model has a variety of types such as Team Games Tournament (TGT), Student Team Achievement Division (STAD), Jigsaw, Group Investigation (GI), Think Pair and Share model, Decision Making Model, Debate Model, Mind Mapping Model, Examples Non Examples, Model, Make-A Match, Picture And Picture Model, Snowball Throwing Model, Stick Talking Model, and many other models. It should be examined deeper, which type or technique is suitable for specific purpose. In this study found that cooperative learning model of group investigation type effectively improve the learning achievement of mathematics. However, cooperative learning type of group investigation in this research was applied based on Bruner's theory that emphasized the learning of Mathematics by manipulating concrete objects. It remains to be seen whether cooperative learning model of group investigation type remains effective when implemented without the aid of the manipulation of concrete objects. Likewise, it is necessary to examine the effectiveness of this learning model for theme learning or other subjects other than Mathematics.

It is important to note also that this study was only done on the fourth grade of elementary school students. The effectiveness of cooperative learning model of group investigation still needs to be tested in other elementary school students of other grade or even at other school level, such as in junior high school or high school.

The assignment of subjects into the experimental and control groups in this study cannot be done randomly, consequently it is not impossible that the experimental and control groups have differences in some factors that may affect learning outcomes. This situation is often referred to as bias selection in experimental research. This may cause the internal validity of this experimental study in doubt. To overcome this matter, in this research was done equality test of Mathematics learning achievement of 10 classes of grade IV students in Gugus II Kecamatan Sukasada. The result of equality test found that the average of Mathematics learning achievement of those 10 classes was equal or not significantly different. However, in order to test more accurately the effectiveness of cooperative learning model of group investigation on Mathematics learning achievement, it is necessary to do research with subject who are assigned into experimental group and control group are chosen randomly. In other words the experimental design needs to be developed from quasi experimental design to true experiment.

Another thing that needs to be stated, teachers who teach in experimental groups and control groups in this study were different teachers. Differences in teacher characteristics can lead to differences in learning processes and achievement. In order to overcome this problem, before the teacher taught both in the experimental group and the control group, a discussion conducted between the researchers and the two teachers to synchronize the perception of general principles of learning. In addition, both teachers have the same academic qualifications of S1 Primary School Teacher Education, same work experience, and rank and class of the same. However, it may be important to conduct a study to test the effectiveness of cooperative learning model of group investigation type using the same teacher between the one in the experimental group and the one in the control group.

\section{CONCLUSION}

Based on the results of research and discussion that has been presented, it can be concluded that Cooperative Learning Model Group Investigation based on Bruner's Theory is a model of learning that can be recommended to use in learning Mathematics in primary schools, especially for students grade IV.

\section{REFERENCES}

[1] J. Piaget Cognitive Development in children: Piaget Development and Learning, J. Res. in Sci. Teaching, , vol. 2, 1964, pp. 176-186

[2] B. Ojose, Applying Piaget's Theory of Cognitive Development to Mathematics Instruction. The Mathematics Educator, Vol. 18, No. 1, 2008, pp. 26-30

[3] D. Susanti, Pengaruh Penerapan Metode Inkuiri Terhadap Hasil Belajar Matematika Pada Siswa Kelas V SD Negeri 1 Rajabasa Raya Bandar Lampung Tahun Pelajaran 2015/2016. Skripsi. Bandar Lampung: Fakultas Keguruan Dan Ilmu Pendidikan Universitas Lampung, 2016.

[4] I. Kurniasih, B. Sani, Model Pembelajaran. Yogyakarta: Kata Pena, 2015.

[5] Heruman, Model Pembelajaran Matematika Di Sekolah Dasar. Bandung: PT Remaja. Rosdakarya, 2007.

[6] Trianto, Model Pembelajaran Terpadu. Jakarta: PT Bumi Aksara, 2010.

[7] L. K. Y. Li, A Study of the Attitude, Self Efficacy, Effort and Academic Achievement of City Students towards Research Methods and Statistics. Discovery - SS Student E-Journal Vol. 1, 2012. pp. 154 183

[8] J. S. Mathew, Self-perception and Academic Achievement. Indian Journal of Science and Technology, Vol. 10, 2017, pp. 14.

[9] A.A.G. Agung, Metodologi Penelitian Pendidikan. Malang: Aditya Media Publishing, 2014

[10] S. Sangadji, "Implementation og Cooperative Learning With Group Investigation Model to Improve Learning Achievement of Vocational School Students in Indonesia". International Journal of Learning \& Development, Volume 6, Nomor 1, 2016, pp. 91-103.

[11] V.D. Tran,. "The Effects of Cooperative Learning on the Academic Achievement and Knowledge Retention". International Journal of Higher Education, Volumen 3, Nomor 2, 2014, 131-140.

[12] P \& Y. Wei, Tang, "Cooperative Learning in English Class of Chinese Junior High School". Creative Education, Volume 6, 2015, pp. 397404).

[13] Z . Aziz, , M. A Hossain.. "A Comparison of Cooperative Learning and Conventional Teaching on Students' Achievement in Secondary Math". Procedia Social and Behavioral Sciences, Nomor 9, 2010, pp. .53-62

[14] Altun, "The Effect of Cooperative Learning on Students Achivement and Views on the Science and Technology Course", International Electronic Journal of Elementary Education, Volume 7, Nomor 3, 2015 , pp. 451-468.

[15] E.C, A Alabekee, Samuel, S.D Osaat. "Effect Of Cooperative Learning Strategy on Students Learning Experience And Achievements In Mathematics". International Journal of Education Learning and Development, Volume 3, Nomor 4, 2015 pp. 67-75.

[16] F. Gull, S. Shehzad "Effects of Cooperative Learning on Students Academic Achievement". Journal of Education and Learning, Volume 9, Nomor 3, 2015, 246-255.

[17] O.P Ajaja, O.U Eravwoke, "Effect of Cooperative Learning Strategy on Junior Secondary School Students Achievement in Integrated Science". 
Electronic Journal of Science Education, Volume 14, Nomor 1, 2010. pp. $1-18$
[18] A. Lie, Cooperative Learning: Mempraktikkan Cooperative Learning di Ruang-Ruang Kelas Jakarta: Penerbit Grasindo 2010 